\title{
"SEMANA WANDA DE AGUIAR HORTA"
}

A Escola de Enfermagem da Universidade de São Paulo, instituiu, em agosto de 1986, a "Semana Wanda de Aguiar Horta", em justa homenagem à saudosa Professora, uma das pioneiras da enfermagem científica no Brasil.

Neste ano, completaram-se cinco anos de seu falecimento e se viva estivesse, a Professora Doutora Wanda de Aguiar Horta estaria comemorando o seu sexagésimo aniversário de nascimento.

A "Semana Wanda de Aguiar Horta" será promovida, anualmente, nesta Escola, procurando ensejar à comunidade de enfermagem, momentos de reflexão e de estudos para dar continuidade aos trabalhos legados pela ilustre Professora, sobretudo relativas à Teoria das Necessidades Humanas Básicas e Metodologia de Assistência de Enfermagem.

"Semana Wanda de Aguiar Horta" de 1986 incluiu em seu programa os seguintes temas:

Wanda de Aguiar Horta e a Enfermagem Brasileira; A Teoria das Necessidades Humanas Básicas - Um Marco Indelével na Enfermagem Brasileira; O pensar, agir e fazer enfermagem de Wanda de Aguiar Horta; O Ensino da Metodologia Assistencial de Enfermagem e A Metodologia Assistencial de Enfermagem na Prática.

Esses temas foram apresentados por destacadas figuras da Enfermagem Brasileira que em muito enriqueceram os trabalhos da Semana Wanda de Aguiar Horta. 